\title{
DETERMINATION OF BLOOD HALOTHANE LEVELS BY GAS CHROMATOGRAPHY*
}

\author{
Richard H. Gadsden, PH.D., K. Benjamin H. Risinger, B.S., \\ AND ERVIN E. BAGWELL, PH.D.
}

THE USEFUlness of gas chromatography as an analytical tool for the identification and quantitation of volatile materials is well documented.1,2 Recently it has been suggested that this sensitive means of detection may be utilized for the analysis of anaesthetic agents. ${ }^{3,4}$ Subsequently, its usefulness for determination of anaesthetic levels in biological material has been demonstrated. ${ }^{5-8}$ The method proposed here is for the determination of halothane in blood by gas chromatographic analysis. The technique for separation of this anaesthetic from blood is simple, rapid, and accurate based upon tests of recovery and reproducibility. It lends itself well to serial determinations which may be required in laboratory or clinical investigations. The maximum error which may be anticipated on a single sample analysis is within \pm 5 per cent.

\section{Apparatrus}

The instruments utilized in this investigation were a Beckman Model GC-2 gas chromatograph with a thermal conductivity detector and Bristol Dynamaster recorder ( $1 \mathrm{mv}$. response full scale). All chromatograms were performed under the following conditions: temperature (injection port, column, detector), $130^{\circ} \mathrm{C}$; attenuation, 1; detector current, 350, ma.; chart recorder speed, $0.5 \mathrm{in} . / \mathrm{min}$.

The chromatograph column used was 12 foot $1 / 1$ inch copper tubing containing di-2-ethylhexylsebacate 1 as the fixed phase on a supporting medium of 20-60 mesh firebrick. After sieving of this preparation to the afore-mentioned mesh size, the chromatograph column was packed and prepared by the following method. The copper tubing was straightened out to its fullest length, one end plugged loosely with glass gauze, and the tubing allowed to hang freely in a vertical position down a stairwell. The filler was poured very slowly into the tubing, and packing was effected by holding a vibrator against the tubing starting at the lower end and working upward as the tube filled. The upper end of the tubing was then plugged with glass gauze. Finally, the tubing was coiled to fit the chromatograph oven by use of a mandrill made for this purpose. All hardware connections were of the brass Swage-Lok type. The column was placed in the chromatograph system and conditioned overnight (approximately 12 hours) at $160^{\circ} \mathrm{C}$. and a helium flow of 20 p.s.i.

All chromatographs were performed with helium as the carrier gas maintained

From the Departments of Chemistry and of Pharmacology, Medical College of South Carolina, Charleston, South Carolina.

fTwo and one-half per cent di-2-ethylhexylsebacate on firebrick, W. H. Curtin \& Co., Jacksonville, Florida (catalogue No. 8787-7D). 
at 60 p.s.i. The $50 \mu \mathrm{l}$. Hamilton micro liquid sampler (Hamilton No. 705 syringe) was used for injection of samples into the chromatograph instrument.

An all-glass distilling apparatus and method of distillation as previously described ${ }^{8,10,11}$ were utilized for isolation of halothane and its distillation carrier (toluene) from blood in preparation for chromatographic analysis.

\section{Sampling and Materials}

\section{Blood}

Heparinized blood was collected for all analyses. Arterial and venous samples were taken from indwelling catheters in dogs. Care was taken to avoid excess suction during withdrawal of the sample. Pipetting of the blood into the distilling Hask was done directly from the syringe to avoid possible loss of halothane due to volatilization (in our hands we have found that excessive manipulation of the sample did result in gross losses). If distillation of the sample(s) was not carried out immediately, they were stored under refrigeration for up to 4 hours. Longer storage was carried out in the deep freeze $\left(-17^{\circ} \mathrm{C}\right.$.). Daily analysis of the same blood stored under the latter conditions revealed that halothane was stable for up to 4 days. ${ }^{9}$

\section{Reagents}

Sodium tungstate-sodium sulphate: $200 \mathrm{gm}$. anhydrous sodium tungstate and $100 \mathrm{gm}$. sodium sulphate are dissolved and diluted to 1 litre with distilled water. Hereinafter this is referred to as Solution $\mathbf{A}$.

Sulphuric acid-sodium sulphate: $200 \mathrm{gm}$. sodium sulphate are dissolved and diluted to 1 litre with $N$ sulphuric acid. Hereinafter this is referred to as Solution B.

( NOTE: The use of Solutions $\mathrm{A}$ and $\mathrm{B}$ as outlined under "Procedure" is adequate for the complete precipitation and foam prevention of 5 c.c. of blood. If it is necessary to use a larger aliquot of sample the reagents should be increased proportionately.)

Toluene, AR: This reagent should be chromatographed before use as described by injection of a $50 \mu \mathrm{l}$. aliquot under the chromatographic conditions outlined. In the event of interfering extraneous peaks these may easily be eliminated by distillation utilizing a 3-foot Vigreaux column.

Potassium carbonate, $\mathbb{A R}$, anhydrous.

Halothane: 2-bromo-2-chloro-1:1:1-trifluoroethane; BP 50.2 $\mathrm{C}$. (Ayerst Laboratories, New York, N.Y.). This reagent is checked for extraneous peaks as under "Toluene" before use in preparation of standards. We have never experienced the presence of any peaks other than that for halothane. Before pipetting for preparation of standards, a small amount of the halothane is dehydrated by addition of potassium carbonate.

\section{Preparation of Halothane Standards}

Obtaining standard weight: A small vial (lower ${ }_{2}$ inch of Wasserman tube or similar) is weighed. To the vial add $0.5 \mathrm{ml}$. of Span 80 (Atlas Powder Co., 
Wilmington, Del.), a few pieces of finely crushed ice, and a micro-spatulatipful of solid $\mathrm{NaCl}$. Weigh. The weight of the vial contents is obtained by difference and this weight is converted to millilitres of water $(1 \mathrm{gm} .=1 \mathrm{ml}$. $)$ and this volume added to a predetermined volume of halothane. This volume of water is then removed from a $\mathbb{1}$ litre volumetric flask which has previously been filled with cold water $\left(10-15^{\circ} \mathrm{C}\right.$. $)$. Halothane, $0.2 \mathrm{ml}$., is added to the vial and its weight is determined (mg.) by difference. The vial and its contents are dropped directly into the volumetric flask. The flask is stoppered and shaken intermittently for 2 hours and allowed to stand overnight. The flask is kept in a refrigerator while not being handled.

For the standardization illustrated (Fig. 1) a total of $0.3581 \mathrm{gm}$. of halothane had been dissolved in the manner described (working standard $=0.358 \mathrm{mg}$. halothane/ml.). For preparation of the standard curve 1.0, 2.0, 3.0, 4.0, 5.0, and $6.0 \mathrm{ml}$. of the working standard was subjected to distillation as described for blood samples. These samples represented $8.95,17.90,26.85,35.80,44.75$, and 53.70 mg.\% halothane, respectively, based upon an anticipated $4 \mathrm{ml}$. blood sample being distilled. The organic supernatant was dehydrated and chromatographed in the identical manner as for the distillates obtained from blood. The method employed here results in obtaining a standard curve (Fig. 1) of straight line function (peak height vs. concentration) and avoids gross loss as would be encountered by dilution of stock standard or laborious preparation of serial standards by absolute weight. The standard curve should be checked before or during each analytical run by incorporating at least two standards (approximately 15 and $50 \mathrm{mg} . \%$ ) into the distillation protocol.

\section{Procedune}

\section{Blood Distillation and Chromatography}

Into the distilling flask containing a few small glass beads are pipetted in sequence: $4 \mathrm{ml}$. Solution $\mathbb{A}$ and $4 \mathrm{ml}$. Solution $\mathrm{B}, 0.25 \mathrm{ml}$. of toluene, and $4 \mathrm{ml}$. of blood. The flask is stoppered, swirled gently for mixing of contents, and allowed to stand until the proteins have been precipitated (assumes a chocolate-brown colour). The flask is then attached to the Vigreaux column portion of the distilling apparatus by means of a water seal and distillation carried out over a small flame from a micro burner. The distillate receiver used is a small vial of 6-7 mm. I.D. and approximately $7 \mathrm{~cm}$. in length (these may be conveniently made by sealing one end of glass tubing of appropriate dimensions). The receiver is contained in a salt-ice-water slush and the condenser tip is kept below the level of the cooling mixture container during distillation. The distillate is collected to approximately three-fourths of the capacity of the receiver. The upper layer of the distillate (consisting of halothane, toluene, and water) is transferred with the aid of a rubber-bulb pipette to a small glass-stoppered flacon contained in a similar cooling mixture as above. Dehydration of the sample is accomplished by the addition of a micro-spatulatipful of anhydrous potassium carbonate (10-15 mg.). The flacon is stoppered and allowed to remain undisturbed for $4-5$ minutes. (The dehydration process is necessary for obtaining good duplicate distillations since 


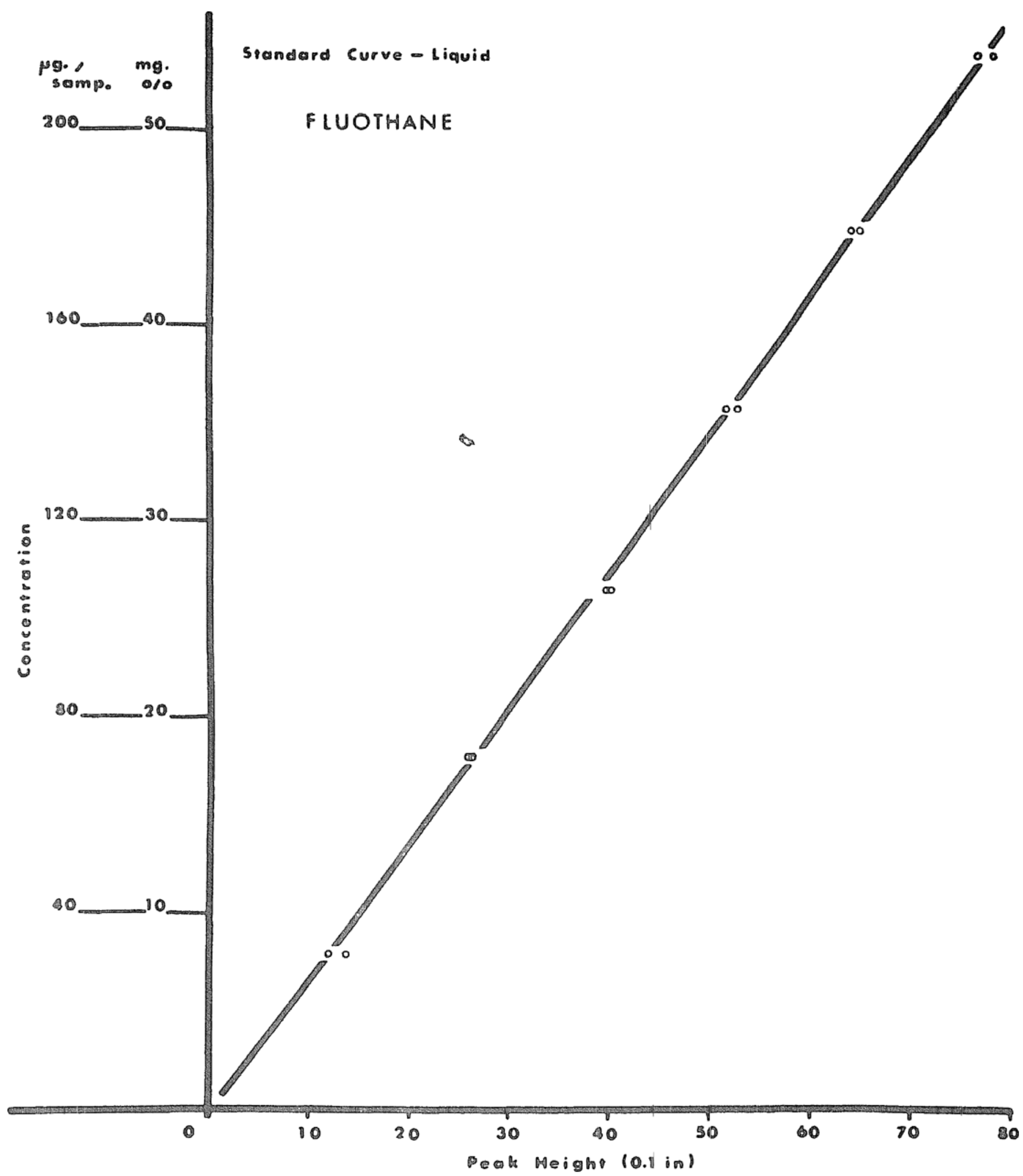

Frgure 1. Standard gas chromatogram curve for halothane (Fluothane) concentration: mg.\% represents concentration of original sample; micrograms per sample represents absolute amount per $25 \mu$ l. injected on chromatograph column. Peak height is in 1/10-inch units.

the varying and trace amounts of water in the distillates tend to have a more or less diluting effect on the absolute amount of halothane present. Also, removal of water has the very desirable effect of preventing the occurrence of a water peak on the chromatogram and "tailing" of the eluted toluene peak.) A $25 \mu$ l. aliquot of the dehydrated toluene distillate is utilized for chromatography under the chromatographic conditions as outlined under the section "Apparatus." The relative elution peaks for air, halothane, and toluene are depicted in Figure 1. 
Routinely the recorder is removed from the system after elution and "baselining" of the halothane peak (approximately 4 minutes). The toluene is then allowed to be eluted before the next distillate sample is injected onto the chromatography column. The column utilized for this investigation has been subjected to well over 1500 injections to date and no deterioration of its stationary phase has occurred as noted by maintenance of constant elution peak times.

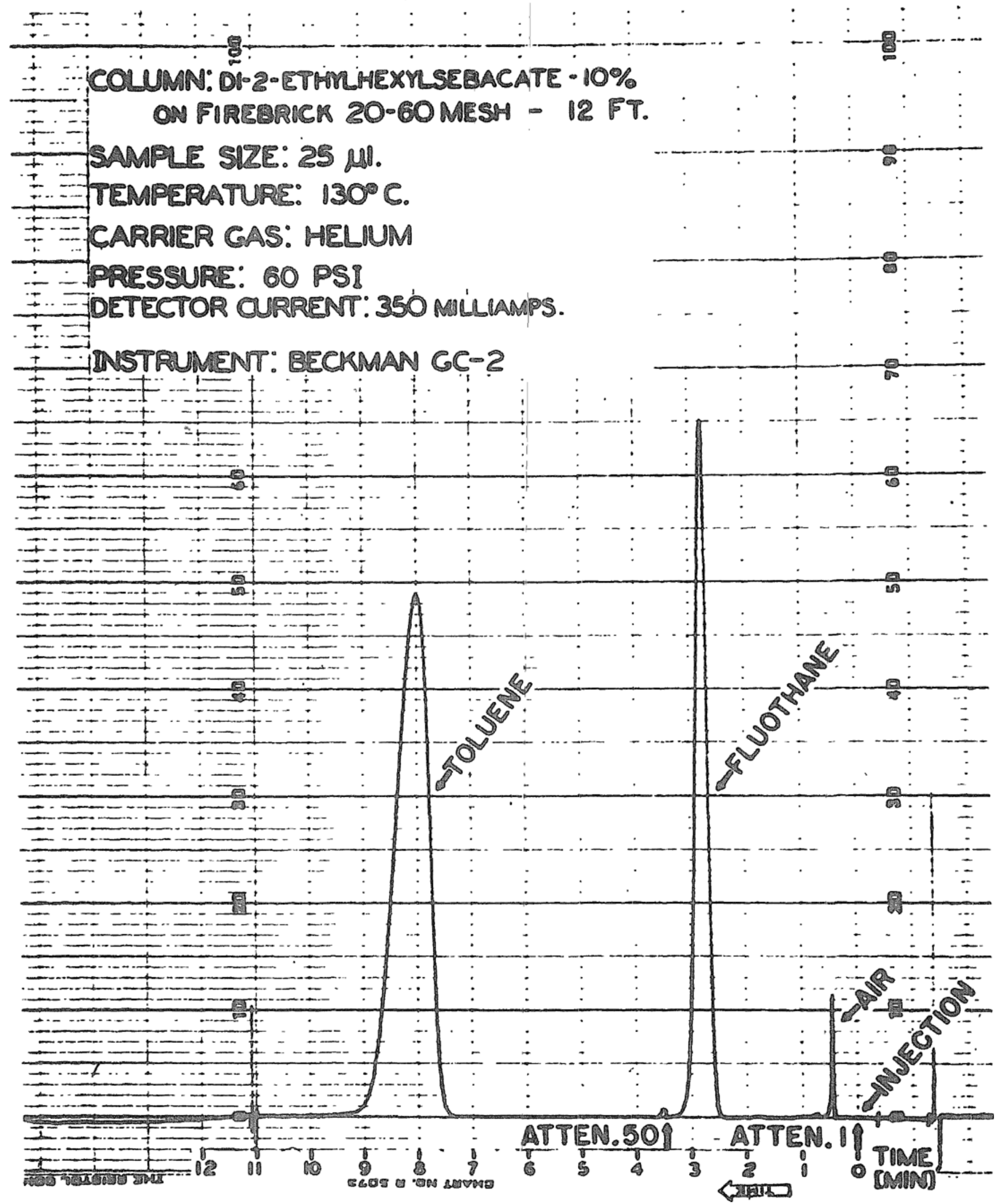

Frgure 2. Mllustrates the relative elution peak times of air, halothane (Fluothane), and the toluene "carrier." Figures above the time scalle and below the chromatogram base-line represent the attenuation settings for obtaining the peaks following. 


\section{Results}

\section{Reproducibility and Recovery Experiments}

Reproducibility experiments were performed to determine the efficiency of the distillation technique and method of sample injection onto the chromatograph column. The method of sample injection is essentially that outlined in previous work..$^{8,11}$ In this testing a work standard was prepared and duplicate aliquots of 2,4 , and $6 \mathrm{ml}$. were distilled, collected, and chromatographed as described. The results set down in Table I are based upon peak heights obtained from duplicate injections of each of the distillates of the respective working standard aliquots as noted. The blood sample results are from a random sample collected during an animal experiment. Calculation of concentrations is based upon peak heights for the unknown compared to the standard curve. Compared to the average standard and blood concentration for each set of experiments, the variation in reproducibility is within \pm 5 per cent.

TABLE I

REPRODUCiBILITY OF METHOD

\begin{tabular}{|c|c|c|c|}
\hline $\begin{array}{l}\text { Peak height } \\
(0.1 \text { in. })\end{array}$ & $\begin{array}{c}\text { Concentration } \\
(\mathrm{mg} . \%)\end{array}$ & $\begin{array}{l}\text { Average } \\
\text { concentration } \\
(\mathrm{mg} . \%)\end{array}$ & $\begin{array}{l}\text { Percentage } \\
\text { of average } \\
\text { concentration }\end{array}$ \\
\hline $\begin{array}{c}2 \text { ml. standard } \\
20.5^{a} \\
19.7 \\
19.5^{b} \\
20.6\end{array}$ & $\begin{array}{l}13.8 \\
13.3 \\
13.2 \\
13.9\end{array}$ & 13.5 & $\begin{array}{r}102.2 \\
98.5 \\
97.8 \\
103.0\end{array}$ \\
\hline $\begin{array}{c}4 \mathrm{ml} . \text { standard } \\
41.6^{\circ} \\
38.9 \\
40.5^{b} \\
39.6\end{array}$ & $\begin{array}{l}28.1 \\
26.3 \\
27.3 \\
26.7\end{array}$ & 27.1 & $\begin{array}{r}103.7 \\
97.0 \\
100.7 \\
98.5\end{array}$ \\
\hline $\begin{array}{l}6 \text { ml. standard } \\
62.7^{a} \\
60.5 \\
59.3^{b} \\
58.2\end{array}$ & $\begin{array}{l}42.3 \\
40.8 \\
40.0 \\
39.3\end{array}$ & 40.6 & $\begin{array}{r}104.2 \\
100.5 \\
98.5 \\
96.8\end{array}$ \\
\hline $\begin{array}{c}4 \mathrm{ml} \text {. blood } \\
48.3^{a} \\
45.6^{6} \\
46.4^{b} \\
48.3\end{array}$ & $\begin{array}{l}32.6 \\
30.8 \\
31.3 \\
32.6\end{array}$ & 31.8 & $\begin{array}{r}102.4 \\
96.8 \\
98.3 \\
102.4\end{array}$ \\
\hline
\end{tabular}

$a, b$ Peak heights of each pair represent duplicate chromatographic elutions of duplicate distillates.

Recovery experiments were carried out to test the additive effect of halothane on that which was present in blood obtained during animal experiments. In essence, the blood concentration was determined from three separate blood samples. Concentrations of standards were obtained. To $4 \mathrm{ml}$. of blood (18 tests) placed in the distillation flask was added varying amounts of standard as noted and distillation performed. The "Total" ( $\mu$ g.) was calculated from previously obtained data and the "Found" ( $\mu \mathrm{g}$. ) was determined by single chromatographic 
injections of triplicate distillates in each case, as noted in Table II. Variations in the method of distillation and chromatography assessed by recovery experiments are within \pm 5 per cent.

TABLE II

RECOVERY EXPERIMENTS

\begin{tabular}{|c|c|c|c|c|c|}
\hline $\begin{array}{c}\text { Sample } \\
\text { No. }\end{array}$ & $\begin{array}{c}\text { Concentration } \\
(\mu \mathrm{g} .)\end{array}$ & $\begin{array}{c}\text { Added }^{b} \\
\left.\text { ( } \mathrm{gg}^{\circ}\right)\end{array}$ & $\begin{array}{c}\text { Tota.l* } \\
\text { ( } \mu \mathrm{g} .)\end{array}$ & $\begin{array}{c}\text { Found } \\
\text { ( } \mu \mathrm{g} .)\end{array}$ & $\begin{array}{c}\text { Recovery } \\
(\%)\end{array}$ \\
\hline $\mathbb{I A}$ & $38.0^{a}$ & 19.2 & 57.2 & $\begin{array}{l}57.6 \\
56.8 \\
57.6\end{array}$ & $\begin{array}{r}100.7 \\
99.3 \\
100.7\end{array}$ \\
\hline B & 38.0 & 38.4 & 76.4 & $\begin{array}{l}72.8 \\
77.6 \\
74.8\end{array}$ & $\begin{array}{r}95.2 \\
101.5 \\
97.8\end{array}$ \\
\hline IIA & $63.6^{n}$ & 23.2 & 86.8 & $\begin{array}{l}84.5 \\
87.9 \\
82.6\end{array}$ & $\begin{array}{r}97.3 \\
101.3 \\
95.2\end{array}$ \\
\hline B & 63.6 & 46.4 & 110.0 & $\begin{array}{l}109.8 \\
113.0 \\
113.2\end{array}$ & $\begin{array}{r}99.8 \\
102.7 \\
102.9\end{array}$ \\
\hline IIIA & $127.2^{a}$ & 23.2 & 150.4 & $\begin{array}{l}145.4 \\
152.7 \\
143.8\end{array}$ & $\begin{array}{r}96.7 \\
101.5 \\
95.6\end{array}$ \\
\hline B & 127.2 & 46.4 & 173.6 & $\begin{array}{l}180.4 \\
170.8 \\
168.6\end{array}$ & $\begin{array}{r}103.9 \\
98.4 \\
97.1\end{array}$ \\
\hline
\end{tabular}

* Micrograms of halothane per $25 \mu$ l. aliquot of distillate (from blood + working standard) chromatographed.

aThis value represents micrograms of halothane per $25 \mu \mathrm{l}$. aliquot of distillate chromatographed. (Original blood concentrations 14.5, 23.9, and $46.5 \mathrm{mg} . \%$, respectively; $4 \mathrm{ml}$. blood distilled.)

${ }^{b}$ These values represent added micrograms of halothane per $25 \mu \mathrm{l}$. aliquot of distillate chromatographed. (Varying volumes working standard added to $4 \mathrm{ml}$. blood and distilled.)

TABLE: III

Animal EXPERiments (DOGS-15 ANimals)

\begin{tabular}{cccc}
\hline $\begin{array}{c}\text { I.C. } \\
(\%)\end{array}$ & $\begin{array}{c}\text { Arterial } \\
(\mathrm{mg} . \%)\end{array}$ & $\begin{array}{c}\text { Venous } \\
(\mathrm{mg} . \%)\end{array}$ & $\begin{array}{c}\text { Samplet } \\
\text { No. }\end{array}$ \\
\hline 0.5 & 8.7 & 7.9 & 17 \\
1.0 & 13.2 & 11.3 & 19 \\
1.5 & 18.2 & 14.2 & 13 \\
2.0 & 22.8 & 19.9 & 17 \\
5.0 & 47.1 & 29.3 & 12 \\
\hline
\end{tabular}

"Inspired concentration of halothane.

$\uparrow$ Denotes number of blood sample (arterial and venous) analyses performed in each case of I.C. noted.

Results are mean values.

\section{Animal Experiments}

Fifteen mongrel dogs were subjected to increasing inhalation concentrations of halothane as noted in Table III. Arterial and venous samples were obtained from indwelling catheters 30 minutes after the animals were placed on the next highest 
inspired concentration of the anaesthetic. Employing the distillation and chromatography technique described, blood concentrations were determined. The data here are average concentrations based upon the number of analyses performed as noted. These data correlate well with those obtained by Chenoweth and co-workers. ${ }^{12}$ Infra-red spectroscopy was the analytical method employed by these workers. These data are presented merely to demonstrate the application of the chromatographic method to animal and clinical studies of anaesthetics of relatively high volatility.

\section{SUMMARY}

A method of isolation by distillation of halothane from blood and its subsequent chromatographic detection and quantitation have been described. The method is simple, rapid, and inexpensive. It lends itself well to incorporation into anaesthetic investigations when blood (and tissue) anaesthetic levels must be obtained in serial manner.

The accuracy of the method, based on tests of reproducibility and recovery, is within \pm 5 per cent. These data are not of a selected nature and represent a testing of the isolation and chromatographic techniques for quantitative analytical adequacy:

Some data obtained from animal experiments are presented. Detailed correlation of these data with cardiovascular and acid-base investigations will appear elsewhere. ${ }^{13}$

\section{RÉSUMÉ}

Nous avons décrit une méthode d'identification de l'halothane par sa distillation du sang et sa détection chromatographique subséquente et son titrage. La méthode est simple, rapide, peu coûteuse. Elle peut être entreprise aussi bien avec d'autres investigations anesthésiques quand les niveaux d'anesthésie dans le sang et dans les tissus doivent être obtenus en série.

La précision de cette méthode basée sur des tests de reproduction et de réveil est de +5 pour cent. Ces valeurs ne sont pas de nature sélective et elles représentent un test d'identification et de technique chromatographique pour une analyse quantitative adéquate.

Nous avons présenté quelques données obtenues des expériences sur des animaux. Nous publierons ailleurs la corrélation détaillée entre ces notions et des investigations sur l'équilibre acide-base et sul: le système cardiovasculaire.

\section{ACKNOWLEDGMENTS}

This investigation was supported by Public Health Service Research Crants NB-03632 from the National Institute of Neurological Diseases and Blindness, and $\mathbb{H E}-05348$ from the National Heart Institute.

\section{REFERENCES}

1. PECsor, R. L. (Editor). Principles and Practices of Gas Chromatography. New York: John Wiley and Sons (1959). 
2. Burcartend, H. P., \& Storas, E. Biochemical Applications of Gas Chromatography. New York: Academic Press (1961).

3. Summers, F. N., \& AdniAn, J. Gas Chromatography: An Analytical Method for Anesthesiology Research. Anesthesiology 22: 100 (1961).

4. Zauder, H. L., \& ORIIN, L. R. Applications of Gas Chromatography to Anaesthesiology. 1. Gases and Vapours. Canad. Anaesth. Soc. J. 10: 228 (1963).

5. Noemaren, T. H., \& Cudmone, J. W. Ethyl Ether Content in Blood as Determined by Gas Chromatography. Anesthesiology 22: 519 (1961).

8. DYFerman, A., \& SJovall, J. Estimation ofl: Fluothane by Gas Chromatography. Acta Anesth. Scandinav. 6: 171 (1962).

7. Butuer, R. A., \& Freman, J. Gas Chromatography as a Method for Estimation of Volatile Anaesthetics in Blood. Brit. J. Anaesth. 34: 440 (1962).

8. GadsDen, R. H.; MCCoRd, W. M.; Woods, E. F.; \& BAGwEL, E. E. Gas Chromatographic Determination of Methoxyflurane in Blood. Anesthesiology 23:. 831 (1962).

9. GADSDEN, R. H., \& HENTz, E. C. Gas Chromatographic Technique for Quantitation of Blood Fluothane Levels. Bull. S. C. Acad. Sci. 25: 35 (1963).

10. GADsDEN, R. H., \& MCCoRD, W. M. A Preparative Technique for Isolation of Materials of Relatively High Volatility for Gas Chromatographic Quantitation. Clin. Chem. 9: 467 (1963). (Presented before the Fifth International Congress on Clinical Chemistry, Aug. 19-23, 1963, Detroit, Michigan.)

11. - - A Preparative Technique for Quantitation of Volatile Materials by Gas Chromatography. J. Gas Chromat. 2: 7 (1984).

12. Chenowith, M. B.; RoBertson, D. N.; ERLifi, D. S.; \& Cohlrge, R. Blood and Tissue Levels of Ether, Chloroform, Halothane, and Methoxytlurane in Dogs Anesthesiology 23: 243 (1962).

13. Bagwen, E. E. GADSDEN, R. H.; \& RumGera, K. B. H. Unpublished viork. Manuscript in preparation. 